\title{
Comparison of the performance of polymerase chain reaction and pp65 antigenemia for the detection of human cytomegalovirus in immunosuppressed patients
}

\author{
Comparação do desempenho da reação em cadeia da polimerase e antigenemia pp65 para \\ detecção de citomegalovírus humano em pacientes imunossuprimidos
}

\begin{abstract}
Patrícia Borba Martiny ${ }^{1}$, Fernanda de-Paris ${ }^{1}$, Alice Beatriz Mombach Pinheiro Machado ${ }^{1}$, Ricardo Obalski de Mello', Martha Bergman Senger ${ }^{2}$, Maria Clara Medina Corrêa ${ }^{2}$, Luiz Carlos Werres Junior ${ }^{2}$ and Carolina Fischinger Moura de Souza ${ }^{3}$
\end{abstract}

\begin{abstract}
Introduction: Human cytomegalovirus (HCMV) is often reactive in latently infected immunosuppressed patients. Accordingly, HCMV remains one of the most common infections following solid organ and hemopoietic stem cell transplantations, resulting in significant morbidity, graft loss and occasional mortality. The early diagnosis of HCMV disease is important in immunosuppressed patients, since in these individuals, preemptive treatment is useful. The objective of this study was to compare the performance of the in-house qualitative polymerase chain reaction (PCR) and pp65 antigenemia to HCMV infection in immunosuppressed patients in the Hospital de Clínicas of Porto Alegre (HCPA). Methods: A total of 216 blood samples collected between August 2006 and January 2007 were investigated. Results: Among the samples analyzed, 81 (37.5\%) were HCMV-positive by PCR, while $48(22.2 \%)$ were positive for antigenemia. Considering antigenemia as the gold standard, sensitivity, specificity, positive predictive values and negative predictive values for PCR were $87.5 \%$, $76.8 \%, 51.8 \%$ and $95.5 \%$ respectively. Conclusions: These results demonstrated that qualitative PCR has high sensitivity and negative predictive value (NPV). Consequently PCR is especially indicated for the initial diagnosis of HCMV infection. In the case of preemptive treatment strategy, identification of patients at high-risk for HCMV disease is fundamental and PCR can be useful tool. Keywords: Human cytomegalovirus. Antigenemia. Polymerase chain reaction. Immunosuppressed patients. Preemptive therapy.
\end{abstract}

\section{RESUMO}

Introdução: O citomegalovírus humano (HCMV), causador de infecção latente, reativa com frequência em pacientes imunossuprimidos. Portanto, o HCMV permanece uma das infecções mais comuns após transplantes de órgãos sólidos e de células hematopoiéticas resultando em significativa morbidade, perda do enxerto e ocasional mortalidade. Assim, o diagnóstico precoce para uma terapia preventiva é de grande importância. Este estudo visa comparar o desempenho dos métodos PCR qualitativo in-house e antigenemia pp65 para o diagnóstico de infecção por CMV em pacientes imunossuprimidos do Hospital de Clínicas de Porto Alegre. Métodos: O estudo foi realizado em 216 amostras de sangue total (EDTA) coletadas de 85 pacientes, entre agosto de 2006 e janeiro de 2007. Resultados: Dentre as 216 amostras analisadas, 81 (37,5\%) amostras apresentaram resultados positivos na PCR, enquanto 48 (22,2\%) apresentaram resultados positivos na antigenemia. A sensibilidade, especificidade, valor preditivo positivo e valor preditivo negativo para a PCR, considerando antigenemia como padrão foram 87,5\%,76,8\%, 51,8\% e 95,5\%, respectivamente. Conclusões: Estes resultados demonstraram que a PCR tem alta sensibilidade e valor preditivo negativo. Consequentemente PCRé especialmente indicada para o diagnóstico inicial de infecção por HCMV. No caso da estratégia de terapia preventiva, a identificação de pacientes com alto risco para a doença por HCMV é fundamental e a PCR pode ser uma ferramenta útil.

Palavras-chaves: Citomegalovírus humano. Antigenemia. Reação em cadeia da polimerase. Pacientes imunossuprimidos. Terapia preemptiva.

1. Unidade de Microbiologia e Biologia Molecular, Serviço de Patologia Clínica, Hospital de Clínicas de Porto Alegre, Porto Alegre, RS. 2. Unidade de Bioquímica e Imunoensaios, Serviço de Patologia Clínica, Hospital de Clínicas de Porto Alegre, Porto Alegre, RS. 3. Serviço de Genética, Hospital de Clínicas de Porto Alegre, Porto Alegre, RS.

Address to: Dra. Fernanda de Paris. Unidade Microbiologia e Biologia Molecular/Serviço Patologia Clínica/HCPA. Rua Ramiro Barcelos 2350, 90035-930 Porto Alegre, RS, Brasil.

Phone: $55513359-8860$

e-mail: fparis@hcpa.ufrgs.br

Received in 20/01/2010

Accepted in 17/01/2011

\section{INTRODUCTION}

Human cytomegalovirus ( $\mathrm{HCMV}$ ) is a ubiquitous pathogen and frequently reactive in latently infected immunosuppressed patients ${ }^{1,2}$. Accordingly, HCMV remains one of the most common infections following solid organ and hemopoietic stem cell transplantations, resulting in significant morbidity, graft loss and occasional mortality. The adverse impact of HCMV infection on graft function underscores the importance of HCMV diagnosis for these patients ${ }^{3}$. In addition, nowadays a preemptive treatment approach is preferable to universal antiviral prophylactic treatment for HCMV infection ${ }^{4}$. Therefore, laboratory techniques are important for monitoring and diagnosing HCMV infection in immunosuppressed patients.

Serological techniques have no role in the diagnosis of active HCMV disease posttransplantation. Viral culture of blood to detect HCMV has limited clinical utility for disease diagnosis due to poor sensitivity ${ }^{3}$. Thus, diagnosis of HCMV infection includes the development of assays to determine infectious viruses (viremia), pp65-positive leukocytes (antigenemia) and viral genome in the blood (DNAemia) ${ }^{4}$. Antigenemia is the first laboratory method routinely used that provides a quantitative parameter for determining the proportion of the antigen pp65 in the nucleus of infected neutrophils in the blood of patients ${ }^{5}$. In recent years, PCR has been widely used in the detection of the HCMV genome, with greater sensitivity compared to that of viral isolation in cell cultures. PCR can provide quantitative and qualitative results with certain advantages, such as greater flexibility with samples, storage at $-20^{\circ} \mathrm{C}$ and the possibility of repeating tests ${ }^{6,7}$. The use of PCR with peripheral blood leukocytes is also more appropriate in cases of small loads, such as when antiviral therapy is already in progress ${ }^{4}$. In addition, a qualitative 
PCR assay may be more appropriate for diagnosis of the disease than for monitoring treatment response. Qualitative PCR can be an option for surveillance if this is the only testing option available ${ }^{3}$.

However, no clinical consensus exists regarding which techniques must be applied to follow immunosuppressed patients at risk of HCMV disease. Considering this fact, this study aimed to contribute to current understanding of the advantages and disadvantages of each technique, using the STARD consensus to improve the evaluation process ${ }^{8}$.

\section{METHODS}

The study was conducted on 216 blood samples (EDTA) collected between August 2006 and January 2007, obtained from attendances at a tertiary hospital, Hospital de Clínicas in Porto Alegre, capital of the State of Rio Grande do Sul, Brazil. The samples were subjected to the antigenemia technique by indirect immunofluorescence (Brite ${ }^{\mathrm{TM}}$ Turbo), performed simultaneously with the qualitative polymerase chain reaction (Nested PCR). To perform the antigenemia assay, a cell fraction was separated using dextran (enriched fraction of polymorphonuclear cells). Monoclonal antibodies were used in this fraction directed against the viral antigen pp65, a protein from the HCMV matrix. The presence of antigen pp65 was detected in the nucleus of infected neutrophils by indirect immunofluorescence. The quantitative reading of $2 \times 10^{5} \mathrm{PBL}$ (peripheral blood leukocytes) was used. This procedure follows the instructions provided by IQ Products ${ }^{\circledR}$, manufacturer of the CMV Bride ${ }^{\mathrm{TM}}$ Turbo Kit ${ }^{\circledR}$.

The samples tested by PCR were subjected to leukocyte separation by density gradient. In this technique, these cells are suspended in sterile water and the viral DNA is extracted using the QIAmp Viral ${ }^{\circledR}$ (Qiagen $\AA$ ) kit according to the manufacturer's instruction manual. An in-house technique of nested PCR was used for molecular determination. This technique uses two stages of consecutive amplification, with the product of the first reaction (347bp) serving as the target for the second (297bp); i.e., in this technique the primers from the second amplification are located inside the primers from the first amplification. The external primers (5’ TG AGG AAT GTC AGC TTC 3' \& 5' TC ATG AGG TCG TCC AGA 3') and internal primers (5' CCA GCC TCA AGA TCT TCA T 3' \& 5' TCG TCC AGA CCC 'TG AGG TA 3') amplify fragments of the $\mathrm{B}$ glycoprotein gene present in the DNA of $\mathrm{HCMV}^{10}$.

Each PCR reaction in the first stage contained $16 \mathrm{mM}\left(\mathrm{NH}_{4}\right)_{2} \mathrm{SO}_{4}$, $67 \mathrm{mM}$ Tris- $\mathrm{HCl}\left(\mathrm{pH} 8.8\right.$ to $25^{\circ} \mathrm{C}$ ), $1.5 \mathrm{mM} \mathrm{MgCl}_{2}, 0.01 \%$ (w/v) of Tween-20, $250 \mathrm{mM}$ dNTP, $5 \mu \mathrm{M}$ of external primers and $1.25 \mathrm{U}$ of polymerase DNA Super-Therm (JMRHolding $\left.{ }^{\circledR}\right)$. The final volume of the reaction mixture was $50 \mu \mathrm{L}$, containing $10 \mu \mathrm{L}$ of DNA extracted from the sample. Amplification was conducted in a Techne ${ }^{\circledR}$ thermocycler. The reaction began with denaturing at $94^{\circ} \mathrm{C}$ for $1 \mathrm{~min}$ and 40 s, followed by 33 cycles at $94^{\circ} \mathrm{C}$ for 30 s, annealing at $50^{\circ} \mathrm{C}$ for $30 \mathrm{~s}$ and polymerization at $72^{\circ} \mathrm{C}$ for $30 \mathrm{~s}$. In the second amplification reaction, a reaction mixture identical to the first was used; however, with half of the individual volumes of the reagents and using the internal instead of the external primers and the addition of $2 \mu \mathrm{L}$ of the amplicon obtained in the first reaction. The reaction began with denaturing at $94^{\circ} \mathrm{C}$ for 45 minutes and 45 seconds, followed by 33 cycles at $94^{\circ} \mathrm{C}$ for $20 \mathrm{~s}$, annealing at $50^{\circ} \mathrm{C}$ for $30 \mathrm{~s}$ and polymerization at $72^{\circ} \mathrm{C}$.

The final products of these reactions were electrophoresed on $2 \%$ agarose gels stained with $0.5 \mu \mathrm{g} / \mathrm{mL}$ ethidium bromide. All testing was performed with negative and positive controls. As negative control, a reaction containing $10 \mu \mathrm{L}$ of sterile water was used instead of the clinical sample. As positive control, an aliquot of NAT (nucleic acid total) of HCMV (Virion ${ }^{\circledR}$ ) was amplified. The results were expressed qualitatively as positive or negative.

For the statistical analysis, the Pearson Chi square test with Yate's correction was used to compare the number of positive samples in both techniques. The level of significance used was $p<0.05$. The agreement between both techniques was determined by the Kappa coefficient. Sensitivity, specificity, positive predictive value (PPV) and negative predictive value (NPV) were calculated for the PCR technique using antigenemia as the gold standard.

\section{Ethical considerations}

The protocol study was approved by the hospital's research ethics committee.

\section{RESULTS}

Of the 216 samples collected in the period described, 85 patients were studied, of which 41 were kidney transplant patients, 24 were bone marrow recipients, 10 were receiving chronic use of immunosuppressive drugs, 8 were liver transplant patients and 2 were HIV seropositive individuals. The positivity rates obtained by both techniques for the 216 samples tested are presented in (Table $\mathbf{1}$ ).

Among the 81 samples positive by PCR, 39 (48.1\%) samples were negative in the antigenemia testing. On the other hand, among the 135 samples negative by PCR, only 6 (4.4\%) showed a positive result for antigenemia (Figure 1).

Considering antigenemia as the gold standard, sensitivity, specificity, positive predictive values and negative predictive values for PCR were $87.5 \%, 76.8 \%, 51.8 \%$ and $95.5 \%$, respectively.

The Kappa value obtained for agreement between both techniques was 0.516 .

TABLE 1 - Percentage positivity of human cytomegalovirus using polymerase chain reaction and antigenemia.

\begin{tabular}{|c|c|c|c|c|c|c|}
\hline & \multicolumn{2}{|c|}{ Positive samples } & \multicolumn{2}{|c|}{ Negative samples } & \multicolumn{2}{|c|}{ Total } \\
\hline & $\mathrm{n}$ & $\%$ & $\mathrm{n}$ & $\%$ & $\mathrm{n}$ & $\%$ \\
\hline Polymerase chain reaction & 81 & $37.5^{*}$ & 135 & 62.5 & 216 & 100.0 \\
\hline Antigenemia & 48 & 22.2 & 168 & 77.8 & 216 & 100.0 \\
\hline
\end{tabular}




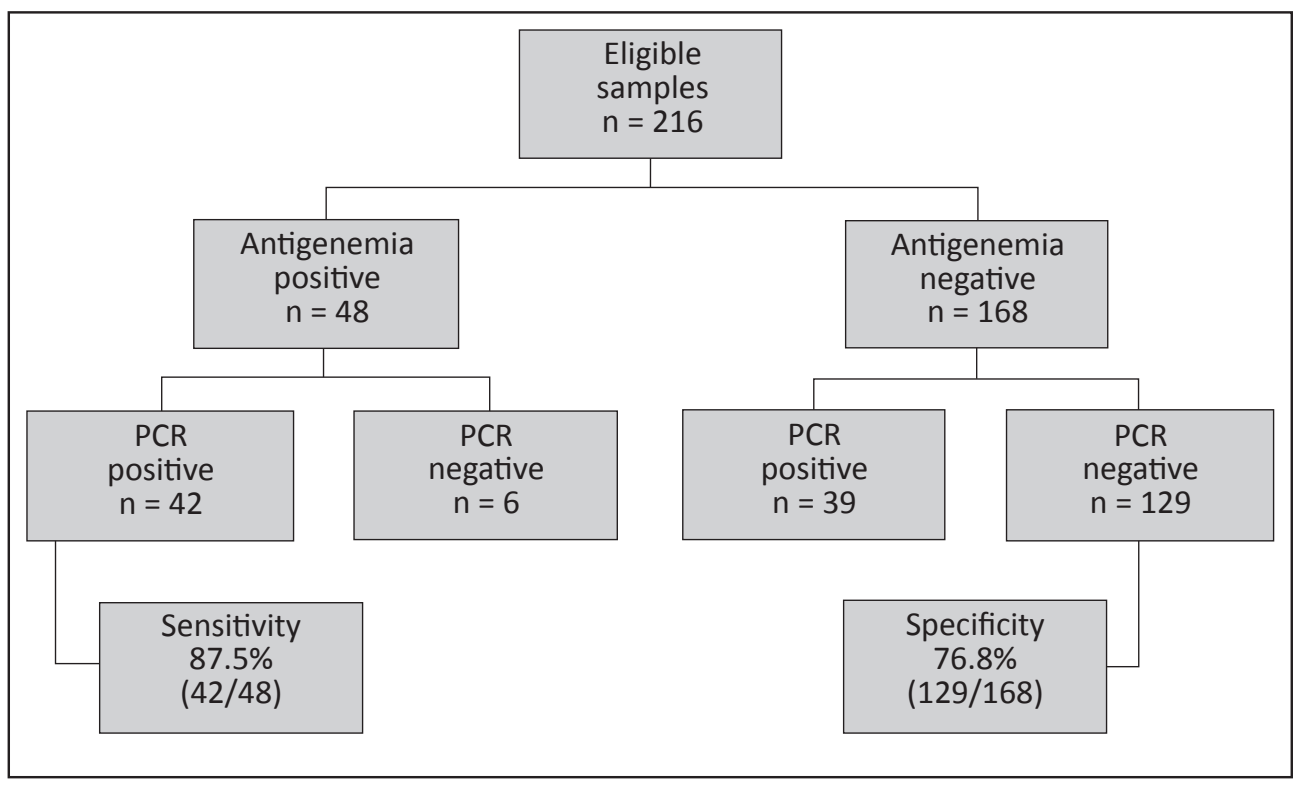

FIGURE 1 - Flowchart showing the results for human cytomegalovirus screening by antigenemia (kit Brite ${ }^{\mathrm{TM}}$ Turbo) vs PCR (in-house).

\section{DISCUSSION}

Human cytomegalovirus infection is a severe pathology and widely affects transplant patients ${ }^{4,5,11-13}$. The concern with the worsening of a patient's health by cytomegalic disease is clearly revealed in the present sample, since of the total of 85 patients followed-up for HCMV viremia, 73 were transplant patients: 41 kidney, 24 bone marrow and 8 liver transplant patients. Analysis of the data showed that the PCR technique was capable of detecting a higher number of positive samples $(81 / 216)$ compared to antigenemia $(48 / 216)$, a statistically significant difference. These results are in agreement with Solano et $\mathrm{al}^{14}$, who reported a greater positivity index for HCMV by PCR in plasma than by pp65 antigenemia ${ }^{14}$. Due to the use of a preemptive treatment strategy for HCMV in transplanted patients, there is a great demand for diagnostic methods that can determine viral replication prior to the manifestation of clinical symptoms. For this reason, diagnostic tests that have high sensitivity and NPV are fundamental for transplanted patients under immunosuppression ${ }^{12}$. In this study, the sensitivity and specificity of PCR were $87.5 \%$ and $76.8 \%$, considering antigenemia as the gold standard. Positive and negative predictive values of PCR were estimated as $51.8 \%$ and $95.5 \%$. Solano et al $^{14}$ and Ksouri et a ${ }^{15}$ reported $86.5 \%$ and $64 \%$ for PCR sensitivity. Therefore, the sensitivity value determined in this work was high and similar to that reported by Solano et $\mathrm{al}^{14}$. However, even antigenemia, which is considered the gold standard, can generate false negative results ${ }^{16-19}$. Thus, the supposedly false positive results in PCR could actually indicate the presence of HCMV in the samples studied. The goldstandard performance affects specificity and positive predictive value parameters. Furthermore, the comparison of the experimental results for both techniques indicated that they are not fully overlapping methodologies. The Kappa value obtained for agreement between both techniques was 0.516 , which reveals a moderate agreement ${ }^{20}$.

On the other hand, when analyzing the raw data from the techniques, observation revealed that among the 81 samples positive by PCR, 39 (48.1\%) samples were negative by the antigenemia test. Furthermore, among the 135 samples negative by PCR, only
$6(4.4 \%)$ showed a positive result by antigenemia (Figure 1). These results attest to the importance of PCR in determining negative patients 5 . The high NPV (95.5\%) showed that PCR could be used on patients without HCMV disease symptoms to indicate which patients required sequential monitoring for HCMV. Thus, patients with no symptoms of HCMV disease and negative PCR would not require monitoring by antigenemia.

The current challenge in HCMV follow-up of immunosuppressed patients is to define the most adequate diagnostic technique for a given clinical situation. Diagnosis and treatment costs and potential side effects should also be considered ${ }^{21}$. Viral load determination by quantitative PCR (real-time PCR) has been reported in literature as a useful technique for HCMV monitoring in immunosuppressed patients ${ }^{17,19,22}$. However, many transplant centers do not have laboratories capable of quantifying HCMV in patient samples. We believe, however, that both qualitative PCR and antigenemia may be used, particularly in transplant centers that do not have access to realtime PCR. This work showed that qualitative PCR has high sensitivity and NPV. Consequently PCR is specifically indicated for the initial diagnosis of HCMV infection. In the case of preemptive treatment strategy, identification of patients at high-risk of HCMV disease is fundamental ${ }^{3,5,11,12}$ and PCR can be a useful tool in these cases.

Molecular monitoring by direct viral genome detection is of greatest utility for patients at high risk of HCMV infection. In this study, higher positivity rates using the PCR method for HCMV DNA screening of peripheral blood of immunosuppressed patients were obtained. Thus, this test could determine the onset of preemptive treatment and meticulous follow-up for such patients.

\section{ACKNOWLEDGMENTS}

The authors are grateful to Prof. Ricardo Machado Xavier and Prof. Afonso Luis Barth for their support.

\section{CONFLICT OF INTEREST}

The authors declare that there is no conflict of interest. 


\section{FINANCIAL SUPPORT}

Research and Event Incentive Fund of Hospital de Clínicas de Porto Alegre (FIPE-HCPA).

\section{REFERENCES}

1. Jenkins FJ, Rowe DT, Rinaldo CR. Herpesvirus Infections in Organ Transplant Recipients. Clin Diagn Lab Immunol 2003; 10:1-7.

2. Wada K, Kubota N, Ito Y, Yagasaki H, Kato K, Yoshikawa T, et al. Simultaneous Quantification of Epstein-Barr Virus, Cytomegalovirus, and Human Herpesvirus 6 DNA in Samples from Transplant Recipients by Multiplex Real-Time PCR Assay. J Clin Microbiol 2007; 45:1426-1432.

3. Kotton CN, Kumar D, Caliendo AM, Asberg A, Chou S, Snydman DR, et al. Transplantation Society International CMV Consensus Group - International consensus guidelines on the management of cytomegalovirus in solid organ transplantation. Transplantation 2010; 89:779-795.

4. Baldanti F, Lilleri D, Gerna G. Monitoring human cytomegalovirus infection in transplant recipients. J Clin Virol 2008; 41:237-241.

5. Gerna G, Lilleri D. Monitoring transplant patients for human cytomegalovirus: diagnostic update. Herpes 2006; 13:4-11.

6. Marin LJ, Cunha AA, Aquino VH, Figueiredo LTM. Desenvolvimento de uma metodologia de PCR semi-quantitativa utilizando plasmídio clonado com parte do gene Gb de citomegalovírus. Medicina Ribeirão Preto 2002 35:85-94.

7. Cunningham R, Harris A, Frankton A, Irving W. Detection of Cytomegalovirus Using PCR in Serum from Renal Transplant Recipients. J Clin Pathol 1995; 48:575-577.

8. Bossuyt PM, Reitsma JB, Bruns DE, Gatsonis CA, Glasziou PP, Irwig LM, et al. Towards Complete and Accurate Reporting of Studies of Diagnostic Accuracy: The STARD Initiative. Clin Chem 2003; 49:1-6.

9. CMV Brite ${ }^{\mathrm{TM}}$ Turbo Kit. Rapid CMV pp65 antigenemia for the detection of active CMV infection. IQ Products ${ }^{\circledR}$ - Bright Fluorescence.

10. Read SJ, Jeffery KJ, Bangham CR. Aseptic meningitis and encephalitis: the role of PCR in the diagnostic laboratory. J Clin Microbiol 1997; 35:691-696.

11. Pescovitz MD. Review of the CMV in renal transplantation. Saudi J Kidney Dis Transpl 2007; 18:505-511.

12. Greanya ED, Partovi N, Yoshida EM, Shapiro RJ, Levy RD, Sherlock CH, et al The role of the cytomegalovirus antigenemia assay in the detection and prevention of cytomegalovirus syndrome and disease in solid organ transplant recipients: A review of the British Columbia experience. J Dis Med Microbiol 2005; 16: 35-341.

13. Ho M. The history of cytomegalovirus and its diseases. Med Microbiol Immunol 2008; 197:65-73.

14. Solano C, Muñoz I, Gutiérrez A, Farga A, Prósper F, García-Conde J, et al. Qualitative Plasma PCR Assay (AMPLICOR CMV Test) versus pp65 Antigenemia Assay for Monitoring Cytomegalovirus Viremia and Guiding Preemptive Ganciclovir Therapy in Allogeneic Stem Cell Transplantation. J Clin Microbiol 2001; 39:3938-3941.

15. Ksouri H, Eljed H, Greco A, Lakhal A, Torjman L, Abdelkefi A, et al. Analysis of cytomegalovirus (CMV) viremia using the pp65 antigenemia assay, the amplicor CMV test, and a semi-quantitative polymerase chain reaction test after allogeneic marrow transplantation. Transpl Infect Dis 2007; 9:16-21.

16. Gimeno C, Solano C, Latorre JC, Hernández-Boluda JC, Clari MA, Remigia MJ, et al. Quantification of DNA in plasma by an automated real-time PCR assay (cytomegalovirus PCR kit) for surveillance of active cytomegalovirus infection and guidance of preemptive therapy for allogeneic hematopoietic stem cell transplant recipients. J Clin Microbiol 2008; 46:3311-3318.

17. Lugert R, Reichard U, Hufert FT, Gross U. Comparison between pp65 antigenemia assay and quantitative real-time polymerase chain reaction for detection of active cytomegalovirus infection in routine diagnostics. Diagn Microbiol Infect Dis 2009; 65:192-195.

18. Sanghavi SK, Abu-Elmagd K, Keightley MC, St George K, Lewandowski K, Boes SS, et al. Relationship of cytomegalovirus load assessed by real-time PCR to pp65 antigenemia in organ transplant recipients. J Clin Virol 2008; 42:335-342.
19. Ghaffari SH, Obeidi N, Dehghan M, Alimoghaddam K, Gharehbaghian A, Ghavamazadeh A. Monitoring of cytomegalovirus infection in bone marrow transplant recipients by real-time PCR. Pathol Oncol Res 2008; 14:399-409.

20. Fleiss AR. Clinical epidemiology. In: Fleiss AR, editors. The arquitecture of clinical research. Philadelphia: W.B. Saunders; 1985. p. 352-376.

21. Granato C. A problemática da infecção pelo citomegalovírus em pacientes imunodeprimidos. Rev Bras Hem Hemot 2001; 23:130-132.

22. Leruez-Ville M, Ouachée M, Delarue R, Sauget AS, Blanche S, Buzyn A, et al Monitoring cytomegalovirus infection in adult and pediatric bone marrow transplant recipients by a real-time PCR assay performed with blood plasma. J Clin Microbiol 2003; 41:2040-2046. 